\title{
KUALITAS PELAYANAN PROGRAM POSYANDU JIWA TERHADAP PASIEN ODGJ (ORANG DENGAN GANGGUAN JIWA) DI DESA MOJOTAMPING KABUPATEN MOJOKERTO
}

\author{
Dwieka Septiani Adiwinoto \\ S1 Ilmu Administrasi Negara, Fakultas Ilmu Sosial dan Hukum, Universitas Negeri Surabaya \\ dwieka.17040674076@mhs.unesa.ac.id \\ Trenda Aktiva Oktariyanda \\ S1 Ilmu Administrasi Negara, Fakultas Ilmu Sosial dan Hukum, Universitas Negeri Surabaya \\ trendaoktariyanda@unesa.ac.id
}

\begin{abstract}
Abstrak
Pemasungan identik dengan permasalahan yang terkait dengan penyakit gangguan jiwa. Di wilayah Jawa Timur sendiri khususnya pada Kabupaten Mojokerto dengan adanya pandemi saat ini terjadi peningkatan sebesar 31,1\% kasus baru, dan apabila kasus gangguan jiwa tersebut tidak segera ditangani maka akan berdampak pada tingkat kesulitan sembuh terhadap pasien gangguan jiwa. Program Posyandu Jiwa, yang dilaksanakan oleh Kabupaten Mojokerto sebagai langkah awal dalam pengurangan kasus gangguan jiwa yang ada. Desa Mojotamping sebagai desa yang memiliki pasien terbanyak di Kabupaten Mojokerto perlu menjamin kualitas pelayanan Posyandu Jiwa supaya dapat menurunkan angka kematian gangguan jiwa akibat bunuh diri. Tujuan dari penelitian ini adalah untuk mendeskripsikan dan mengukur kualitas pelayanan Posyandu Jiwa terhadap pasien gangguan jiwa di Desa Mojotamping. Peneliti menggunakan jenis penelitian deskriptif dengan menggunakan pendekatan kualitatif. Fokus penelitian ini menggunakan teori kualitas pelayanan Vincent Gesperzs yaitu ketepatan waktu pelayanan, akurasi, kesopanan dan keramahan, tanggung jawab dalam keluhan, sedikit banyaknya petugas yang melayani, berkaitan dengan lokasi, dan berhubungan dengan kondisi lingkungan. Melalui hasil penelitian yang telah dilaksanakan kualitas pelayanan program Posyandu Jiwa terhadap Pasien ODGJ di Desa Mojotamping Kabupaten Mojokerto dapat dikatakan cukup bagus, hanya saja sedikit kurang dari segi lokasi, ruang tunggu dan ruang proses perawatan yang terbilang cukup sempit dan kebersihan yang kurang karena kondisi lingkungan yang rata - rata berdebu.
\end{abstract}

Kata Kunci : Kualitas Pelayanan, ODGJ, Posyandu Jiwa

\begin{abstract}
Shackling is synonymous with problems related to mental disorders. In the East Java region itself, especially in Mojokerto Regency, with the current pandemic there has been an increase of $31.1 \%$ new cases, and if these mental disorders cases are not treated immediately it will have an impact on the level of difficulty recovering for mental patients. The Posyandu Jiwa program, which is implemented by Mojokerto Regency as a first step in reducing existing mental disorders cases. Mojotamping Village as the village with the most patients in Mojokerto Regency needs to ensure the quality of Posyandu Jiwa services so that it can reduce the death rate for mental disorders due to suicide. The purpose of this study was to describe and measure the quality of Posyandu mental services for mental patients in Mojotamping Village. Researchers used descriptive research using a qualitative approach. The focus of this study uses Vincent Gesperzs' service quality theory, namely service timeliness, accuracy, politeness and friendliness, responsibility in complaints, more or less officers serving, location-related, and environmental conditions. Through the results of research that has been carried out, the quality of the Posyandu Jiwa program for ODGJ patients in Mojotamping Village, Mojokerto Regency can be said to be quite good, it's just a little less in terms of location, waiting room and room for the treatment process which are quite narrow and lack of cleanliness due to environmental conditions. average dusty.
\end{abstract}

Keywords : Quality of Service, Mental Disorders, Mental Posyandu 


\section{PENDAHULUAN}

Dalam pemenuhan kebutuhan, tiap orang wajib dapat melayani dirinya sendiri dalam memenuhi kebutuhan hidup. Hal tersebut membuktikan bahwasanya, tiap individu membutuhkan adanya pelayanan. Oleh karenanya salah satu fungsi pemerintah adalah menyediakan fungsi pelayanan (Warsono et al., 2018). Negara sebagai pelaksana pelayanan yang disediakan oleh pemerintah dan swasta, menyediakan berbagai macam fasilitas pelayanan yang ditawarkan kepada masyarakat yang tidak dapat dilaksanakan oleh tiap individu. Dimulai dengan jenis pelayanan yang bersifat administratif, pelayanan barang, dan pelayanan jasa (Kemenpan, 2003). Berbagai macam bidang apapun, kualitas pelayanan juga diperlukan sebagai peningkatan mutu pelayanan. Karena saling bersinggungan dengan kepuasan pelanggan, menghasilkan dampak yang mengakibatkan adanya perbaikan secara terus menerus seiring dengan berkembangnya jaman (Machmud, 2008).

Pada era ini, banyak ditemukan inovasi pelayanan dalam bidang kesehatan yang tidak hanya menyembuhkan, tetapi juga mengedepankan pada sifat pelayanan yang mencegah untuk meningkatkan kualitas hidup dan kepuasan pelanggan (Andriani, 2017). Khususnya pada sektor publik, inovasi dianggap penting untuk meningkatkan kualitas hidup dan kepuasan pelanggan (Eprilianto et al., 2019). Inovasi tersebut dibutuhkan dengan kriteria pelayanan yang semakin mudah, murah, terjangkau, dan merata (Suwarno, 2008). Ketepatan penyampain tersebut diharapkan dapat memenuhi harapan dalam pemenuhan kebutuhan dan keinginan pelanggan. Tersedianya pelayanan kesehatan yang berkualitas, merupakan salah satu bentuk perwujudan pemerintah dalam pembangunan di bidang kesehatan (Handayani, 2016). Program pembangunan kesehatan tersebut mencakup 5 aspek dalam pelayanan kesehatan dasar, antara lain : promosi kesehatan, kesehatan lingkungan, kesehatan ibu dan anak termasuk keluarga berencana, pemberantasan penyakit menular dan pengobatan (Hartono, 2007). Oleh karena itu, untuk mewujudkan program pembangunan kesehatan dasar diperlukan adanya langkah awal dalam berperilaku sehat sebagai bentuk pencegahan diri, atau bagaimana cara mendeteksi penyakit yang ada dalam diri sendiri pada tahap awal gejala (Kasl \& Cobb, 2013).
Penyakit tidak menular seperti gangguan jiwa dan penyakit jantung, akan mengambil alih kedudukan penyakit infeksi dan kekurangan gizi di negara - negara berkembang (Saleh, 2018). Hingga diprediksi pada tahun 2020, kematian akibat penyakit tidak menular diprediksi meningkat menjadi 1 diantara 10 kematian, dibandingkan 30 tahun sebelumnya (HIMPSI, 2020). WHO menyatakan gangguan jiwa umum seperti depresi dan kecemasan adalah penyumbang prevalensi paling tinggi. Dengan total 3,6\% dari populasi (lebih dari 200 juta orang) menderita kecemasan, sedangkan $4,4 \%$ dari populasi (322 juta orang) menderita depresi yang hampir separuhnya berasal dari wilayah Pasifik Barat dan Asia Tenggara (WHO, 2017). Hasil penelitian yang dilakukan oleh WHO menunjukkan bahwasanya kecemasan dan depresi menyebabkan kerugian ekonomi global sebesar 1 trilyun USD tiap tahunnya, dikarenakan hilangnya produktifitas sumber daya manusia (WHO, 2019). Sementara itu, dalam skala nasional prevalensi gangguan emosional pada penduduk berusia 15 tahun ke atas, meningkat dari 6\% di tahun 2013 menjadi 9,8\% di tahun 2018. Prevalensi penderita depresi di tahun 2018 sebesar $6,1 \%$. Riskesdas menunjukkan prevalensi gangguan jiwa berat (skizofrenia), meningkat dari 1,7\% di tahun 2013 menjadi 7\% di tahun 2018 (Riskesdas, 2018).

Tabel 1. Data Riskesdas Prevalensi Gangguan Emosional, Depresi, dan Skizofrenia pada Tahun 2013 - 2018

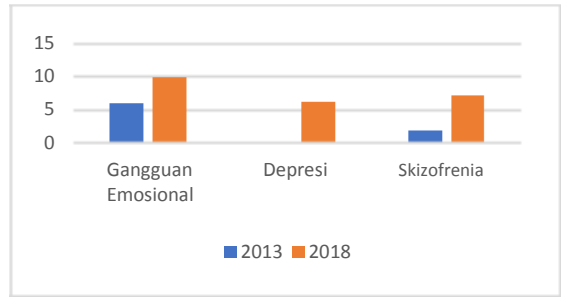

Sumber : . Hasil Utama Riset Kesehatan Dasar

(Riskesdas) Tahun 2018. Kementrian Kesehatan RI.

Berdasarkan data yang telah ditunjukkan pada

Tabel 1, menunjukkan gangguan jiwa tidak memandang kalangan, bisa menyerang anak - anak, remaja, dewasa atau lansia. Di Jawa Timur sendiri, berdasarkan data dari Riskesdas tahun 2013 prevalensi gangguan jiwa berat sebesar 3\%, sedangkan pada tahun 2018 terjadi kenaikan menjadi $6 \%$, yang mana kenaikan ini mengakibatkan posisi Provinsi Jawa Timur dalam kategori gangguan jiwa berat (skizofrenia) pada tahun 2018 menempati posisi ke 20 
(Riskesdas, 2018). Selanjutnya Dinas Kesehatan Provinsi Jawa Timur pada tahun 2019 ini melalui buku Profil Kesehatan Jawa Timur, mengkonfirmasi bahwa angka gangguan jiwa menduduki nomor 1 di Indonesia (Dinas Kesehatan Provinsi jawa timur, 2019). Kenaikan jumlah kasus tersebut disebabkan adanya perbedaan tekanan mental pada setiap orang, kemudian permasalahan lain yang membuat kenaikan pada prevalensi gangguan jiwa berat adalah pandangan masyarakat yang tradisional. Rata - rata masyarakat memandang gangguan jiwa sebagai bentuk rasa kurang bersyukur dan mengaitkan kepada keagamaan (Apriyani, 2019). Pemasungan juga menjadi permasalahan yang serius apabila dikaitkan dengan ODGJ. Praktek pemasungan sendiri dilakukan oleh masyarakat dikarenakan malu dengan kondisi keluarga yang mengidap ODGJ, serta pihak keluarga berusaha menghindar dari amukan pasien ODGJ yang pada umumnya sering merusak barang barang yang ada di sekitarnya. Perlakuan tersebut sangat bertentangan dengan peraturan perundang undangan yang ada. Pada Undang - Undang Nomor 18 Tahun 2014 Tentang Kesehatan Jiwa, mewajibkan pada setiap ODGJ untuk mendapatkan perawatan, pengobatan dan tidak dipasung, karena hal tersebut merupakan bentuk kekerasan terhadap ODGJ (Ulfa, 2018). Gangguan jiwa bukan termasuk dalam kategori kecacatan fisik, oleh karena itu lebih sulit disembuhkan apabila tidak didukung dengan adanya peralatan kesehatan yang memadai (Crowe, Allison \& Averett, 2015).

Berdasarkan grafik terkait dengan prevalensi depresi penduduk di Provinsi Jawa Timur pada tahun 2013 - 2018, wilayah Kabupaten Mojokerto memiliki prosentase sebesar 2,7\% yang menduduki posisi ke 9 terbawah. Sementara pada gangguan mental emosional pada penduduk umur diatas 15 tahun, pada tahun 2013 prevalensi yang dicatat sebesar 7\% hingga menduduki posisi ke 8 teratas, kemudian pada 2018 turun menjadi 4\% dan menduduki peringkat ke 9 terendah di Provinsi Jawa Timur (Riskesdas, 2018). Penurunan prevalensi dari tahun 2013 hingga 2018 tersebut, terdapat realita dimana masyarakat

melakukan praktek pemasungan dan menyembunyikan warga ODGJ dari warga serta Dinas Kesehatan setempat. Oleh karenanya, pada saat evakuasi warga ODGJ di Kabupaten Mojokerto ditemukan kasus pemasungan yang telah terjadi selama 5 tahun (2014 - 2019) lamanya (Budianto, 2019).

Pada masa pandemi Covid - 19 sejauh ini terdapat 1221 orang. Ketua Bidang Pencegahan dan Pengendalian Penyakit (P2P) Dinas Kesehatan Kabupaten Mojokerto, dr. Langit Kresna Janitra menjelaskan bahwa pada tahun 2019 lalu warga yang mengalami gangguan jiwa sebanyak 931 orang, sedangkan sejak awal 2020 hingga masa pandemi per Oktober ini, angkanya mengalami peningkatan $31,1 \%$ atau bertambah sebanyak 290 kasus gangguan jiwa baru (Chariris, 2020). Penambahan kasus baru tersebut pada umumnya didominasi akibat mengalami setress dan depresi akibat berbagai permasalahan yang dihadapi. Apabila kondisi tersebut tidak segera ditangani maka kondisi tersebut dapat meningkat menjadi gangguan jiwa berat, dan memerlukan perawatan yang lebih intensif.

Terkait dengan permasalahan tersebut, pemerintah Kabupaten Mojokerto menyiapkan program penanganan pasien ODGJ dengan membuat inovasi program yang bernama Posyandu Jiwa. Program Posyandu Jiwa sendiri, merupakan sebuah program yang ditujukan kepada pasien ODGJ sebagai bentuk perawatan dan pengobatan yang sesuai dengan peraturan perundang - undangan. Program yang dimulai pada tahun 2019 ini, digagas oleh Dinas Kesehatan Kabupaten Mojokerto sesuai dengan Surat Keputusan Gubernur Jawa Timur Nomor 460/11166/031/2014 tentang Pembebasan Skizofrenia yang Dipasung. Dinas Kesehatan Kabupaten Mojokerto memberikan amanah kepada tiap puskesmas yang ada di wilayah kabupaten untuk membantu desa - desa setempat dalam melaksanakan program tersebut. Dalam pelaksanaannya, pihak puskesmas hanya diberikan instruksi untuk membantu dalam penyediaan obat obatan dan tenaga medis, sisanya untuk fasilitas seperti laboratorium atau yang lainnya ditanggung oleh pihak pemerintah desa itu sendiri. Hingga saat ini, program Posyandu Jiwa masih berjalan khususnya yang berada di wilayah Puskesmas Bangsal. Puskesmas Bangsal yang membawahi 17 desa yang berada di Kecamatan Bangsal. Desa Mojotamping sebagai salah satu desa yang berada di wilayah Kecamatan Bangsal tercatat sebagai desa yang mempunyai jumlah penderita ODGJ terbanyak di Kabupaten Mojokerto dengan jumlah 23 penderita gangguan jiwa pada tahun 2020 . 
Sebagai dasar dalam penelitian ini, peneliti menggunakan penelitian terdahulu milik Pratiwi \& Niswah (2018), Wicaksono \& Susilowati (2019) dan Widoanti \& Meirinawati (2020) terdapat pembeda yang mana ditiap lokasi dalam penelitian memiliki masalah yang berbeda - beda. Pada kasus penelitian yang dikemukakan oleh Pratiwi \& Niswah (2018) terciptanya Program Jebol Pasung (Jemput Bola Pasien Urung Kunjung) yang berada di Kabupaten Madiun dikarenakan terjadi peningkatan jumlah gangguan jiwa berat pada tahun 2013 - 2016, akan tetapi masih sedikit penderita gangguan jiwa yang melakukan pengobatan secara rutin. Pada penelitian yang dilakukan oleh Wicaksono \& Susilowati (2019), Kabupaten Jombang menghadapi permasalahan penggelandangan penderita gangguan jiwa yang dilakukan oleh pihak keluarga. Realitanya hal tersebut melanggar regulasi yang telah dibuat oleh pemerintah yang tercantum dalam Undang Undang Nomor 18 Tahun 2014 tentang Kesehatan Jiwa. Sementara itu, pada kasus penelitian yang dikemukakan oleh Widoanti \& Meirinawati (2020) sebelum adanya program layanan Lesung Si Panji (Lenyapkan Pasung dan Memanusiakan Pasien Jiwa) di Kabupaten Lamongan, data penderita gangguan jiwa yang dipasung sulit dicari karena pihak keluarga cenderung menyembunyikan keluarganya yang menderita gangguan jiwa. Hal tersebut tidak dapat dipungkiri bahwasanya masih banyak masyarakat yang merasa malu memiliki anggota keluarga penderita gangguan jiwa. Oleh karenanya, melalui penelitian tersebut peneliti melihat bahwasanya Kabupaten Mojokerto juga menghadapi permasalahan demikian, yang mana permasalahan pemasungan, penggelandangan yang dilakukan oleh pihak keluarga, serta tidak adanya fasilitas pengobatan yang mendukung sebelum diterapkannya program Posyandu Jiwa. Membuat peneliti tertarik untuk mendeskripsikan kualitas pelayanan program posyandu jiwa terhadap pasien ODGJ di Desa Mojotamping Kabupaten Mojokerto.

\section{METODE}

Jenis penelitian yang peneliti gunakan dalam penelitian ini menggunakan penelitian deskriptif dengan pendekatan kualitatif. Penjelasan mengenai "Kualitas Pelayanan Program Posyandu Jiwa Terhadap Pasien ODGJ (Orang Dengan Gangguan Jiwa) di Desa Mojotamping Kabupaten Mojokerto" menggunakan model teori kualitas pelayanan dari Gespersz (2002) :

1. Ketepatan waktu pelayanan berkaitan dengan waktu tunggu dan proses.

2. Akurasi atau ketepatan pelayanan.

3. Kesopanan dan keramahan pelaku bisnis/pelayanan.

4. Tanggung jawab dalam penanganan keluhan pelanggan.

5. Sedikit banyaknya petugas yang melayani dan fasilitas pendukung lainnya.

6. Berkaitan dengan lokasi, ruangan tempat pelayanan, tempat parkir, ketersediaan informasi, dan petunjuk atau panduan lainnya.

7. Berhubungan dengan kondisi lingkungan, kebersihan, ruang tunggu, fasilitas musik, AC, alat komunikasi, dll.

Teknik analisis data menggunakan model Miles dan Huberman, menggunakan analisis model interaktif yang terdiri dari pengumpulan data, reduksi data, penyajian data, dan kesimpulan. Pengumpulan data yang dilakukan di Ponkesdes Mojotamping berupa wawancara, observasi, dan dokumentasi. Kemudian reduksi data yaitu memilih dan memilah data - data yang penting. Selanjutnya adalah penyajian data dalam penelitian deskriptif dengan pendekatan kualitatif disajikan dalam bentuk uraian teks. Terakhir membuat kesimpulan dari temuan data yang ada di lapangan.

\section{HASIL DAN PEMBAHASAN}

Posyandu Jiwa yang dilaksanakan di seluruh desa Kabupaten Mojokerto yang memiliki warga desa pengidap ODGJ. Program Posyandu Jiwa digagas berdasarkan Surat Keputusan Gubernur Jawa Timur Nomor 460/11166/031/2014 tentang Pembebasan Skizofrenia yang Dipasung, kemudian Dinas Kesehatan Kabupaten Mojokerto menciptakan program tersebut sebagai bentuk sarana pembebasan ODGJ yang dipasung dan menyediakan perawatan bagi ODGJ. Program Posyandu Jiwa yang dilaksanakan di Desa Mojotamping memiliki beberapa strategi dalam pembebasan pasien ODGJ yang dipasung atau dibiarkan berkeliaran oleh keluarganya. Program Posyandu Jiwa yang dimulai sejak tahun 2019 ini, hingga saat ini di Desa Mojotamping memiliki 23 pasien ODGJ dengan kriteria 12 orang laki - laki dan 11 orang perempuan. Pendataan 
dilaksanakan oleh kader posyandu jiwa yang didasarkan pada pengaduan masyarakat dan mendatangi tiap rumah yang memiliki keluarga dengan pasien pengidap ODGJ. Selain melakukan pendataan, kader posyandu juga melakukan koordinasi di tingkat desa dengan tokoh masyarakat, puskesmas terdekat, serta aparat keamanan.

Tujuan umum dengan adanya program Posyandu Jiwa adalah untuk mencegah dan mengurangi resiko gangguan jiwa dan memberikan pengetahuan bagi masyarakat sekitar serta melakukan percepatan penurunan angka gangguan jiwa di Desa Mojotamping. Adapun tujuan khusus dalam program tersebut antara lain :

1. Meningkatkan peran masyarakat dalam pembebasan ODGJ yang dipasung.

2. Meningkatkan pelayanan dan rehabilitasi sosial bagi penderita ODGJ.

3. Terpenuhinya kebutuhan pelayanan dasar bagi penderita ODGJ.

4. Mengembalikan fungsi sosial penderita ODGJ pada keluarga dan masyarakat.

Untuk mengkaji kualitas pelayanan program Posyandu Jiwa di Desa Mojotamping, Kabupaten Mojokerto. Peneliti menggunakan model teori kualitas pelayanan dari Vincent Gespersz dengan tujuh variabel, yaitu :

1. Ketepatan waktu pelayanan berkaitan dengan waktu tunggu dan proses.

Membicarakan terkait dengan waktu tunggu dan proses, merupakan salah satu bentuk dalam menunjang kualitas pelayanan. Hal tersebut dikarenakan, kegiatan menunggu bagi sebagian orang adalah kegiatan yang membuang - buang waktu. Sedangkan waktu proses dalam dunia pelayanan, sangat menunjang kualitas pelayanan. Dalam bidang apapun, masyarakat membutuhkan pelayanan yang memiliki proses cepat serta waktu tunggu yang tidak memakan banyak waktu.

Program Posyandu Jiwa di Desa Mojotamping sendiri diselenggarakan oleh petugas posyandu setiap 1 bulan sekali yang jatuh pada hari Sabtu pada minggu ke 2 atau pada minggu ke 3 pada jam 08.00 WIB sampai dengan jam 15.00 WIB.

"Biasanya mbak, mulai jam 8 pagi itu ada beberapa pasien yang harus dijemput dulu, soalnya kalau gak dijemput itu gak mau berangkat buat berobat, jadi bagusnya pelayanan posyandunya itu ada layanan antar jemput buat pasien - pasien tertentu." -
Keterangan beberapa warga yang mengantarkan keluarganya untuk berobat pada 22 Oktober 2020.

Berdasarkan keterangan tersebut, terkait dengan metode pelayanan yang disediakan oleh petugas posyandu diakui peneliti sebagai inovasi yang bagus sebagai bentuk dukungan dan dorongan kepada masyarakat yang memiliki keluarga ODGJ untuk melakukan pemeriksaan. Metode pelayanan tersebut diberlakukan pada pasien ODGJ yang sudah mengenal petugas posyandu dengan baik. Penyebab munculnya metode pelayanan tersebut, dikarenakan pihak pasien yang dapat digolongkan dalam kelas berat biasanya melawan keluarganya sendiri apabila akan dibawa sendiri, sementara itu apabila dibawa oleh petugas posyandu pasien terkesan lebih tenang dan lebih menuruti perintah yang diucapkan oleh petugas posyandu.

Setelah penjemputan pasien selesai dilaksanakan, petugas posyandu harus segera memilah - milah pasien yang tidak dapat dibiarkan lama - lama atau menganggur terlalu lama. Karena apabila hal tersebut dibiarkan maka pasien akan mengamuk dengan berteriak - teriak dan melemparkan barang - barang yang ada disekitarnya.

"Ada mbak, salah satu pasien yang gak mau nunggu lama - lama. Kalau beliaunya merasa dibiarkan waktu lagi antri giliran, malah ngamuk gak jelas dan terkadang ngelempar - lempar barang atau gak teriak teriak." - Keterangan Bu Rita selaku Pembina Posyandu Jiwa di Desa Mojotamping pada 22 Oktober 2020.

Menurut keterangan tersebut, petugas posyandu memahami pasien ODGJ dengan melaksanakan pemilahan tersebut. Begitu juga dengan pasien lainnya, dalam masa waktu tunggu untuk proses pelayanan, petugas posyandu dengan sabar mengajak pasien dengan aktifitas untuk pengalihan berupa aktivitas memakan jajanan yang telah disediakan oleh pihak petugas posyandu, bernyanyi, dan bermain. Akan tetapi, petugas posyandu jugalah manusia yang tidak pernah luput dari kesalahan, kesalahan yang biasanya terjadi dalam proses penjemputan adalah petugas posyandu sudah sibuk dengan sebagian pasien yang telah datang berobat sehingga pasien yang seharusnya mendapatkan pelayanan antar jemput tidak bisa melakukan pengobatan, hingga akhirnya petugas 
posyandu mengirimkan obat yang dibutuhkan oleh pasien dengan pertimbangan rekam medis pasien.

Sementara itu, pelaksanaan waktu prosesnya pasien ODGJ akan diperiksa seperti pasien pada umumnya. Hanya saja pengecualian disini, pihak keluarga akan mendampingi pasien sebagai sarana penyampaian penyebab gangguan jiwa dan adakah penyakit bawaan lain yang ada pada tubuh pasien.

"Pemeriksaannya ya kayak pasien pada umumnya mbak, kita ada pengecekan untuk gula darah, tekanan darah, asam urat dll. Soalnya rata - rata, ODGJ disini gak hanya ODGJ murni tetapi juga ada yang kena hipertensi, jantung, intinya penyakit orang orang pada umumnya gitu lo mbak". Keterangan Ibu Rita selaku Pembina Posyandu Jiwa di Desa Mojotamping pada 22 Oktober 2020.

Selama proses pemeriksaan, dan apabila membutuhkan data medis yang memerlukan sarana laboratorium, pihak desa menganggarkan untuk pasien ODGJ. Proses penyembuhan pasien ODGJ sangatlah bervariasi, dapat dikatakan pasien melakukan rawat jalan dengan pemberian obat obatan rutin yang disediakan dan dapat diambil langsung di Puskesmas Bangsal atau melalui petugas posyandu yang bertugas. Karena obat - obatan bagi pasien ODGJ merupakan golongan obat psikotropika, diperlukan adanya pengawasan dari dokter dan tidak sembarangan dalam pemberian obatnya. Terdapat pasien yang mengonsumsi obat terus menerus, adapula pasien yang mengonsumsi obat untuk ODGJ kemudian berhenti setelah dinyatakan sembuh oleh pihak dokter, atau terdapat pula pasien yang berhenti meminum obat setelah sembuh kemudian kumat lagi dan wajib meminum obat kembali.

"Kalau masalah obat ya mbak, kan ada obat untuk penyakit umum sama gangguan jiwanya. Dua - duanya itu harus sesuai anjuran dokternya soalnya obat buat gangguan jiwa sendiri bisa digolongkan obat keras (psikotropika). Kalau tiba - tiba berhenti malah bahaya". - Keterangan Ibu Rita selaku Pembina Posyandu Jiwa di Desa Mojotamping pada 22 Oktober 2020.

Pada masa pandemi saat ini, Ibu Rita mengakui bahwa terdapat pasien yang pada tahun 2019 dinyatakan sembuh kemudian pada tahun 2020 sakit lagi. Hal itu juga disebabkan pemicu yang menyebabkan pasien menjadi kambuh kembali. Rata - rata permasalahan yang menyebabkan pasien demikian adalah permasalahan ekonomi, rumah tangga, dan asmara.

2. Akurasi atau ketepatan pelayanan.

Apabila membicarakan terkait dengan akurasi atau ketepatan pelayanan dapat dikaitkan dengan efektifitas dan efisiensi. Kedua hal tersebut menjadi sangat krusial dikarenakan dalam bidang kesehatan khususnya pada kesehatan jiwa pelaksanaan efektifitas difokuskan kepada tingkat kesembuhan pasien, apakah pasien tersebut membaik atau malah memburuk. Sedangkan pelaksanaan efisiensi berkaitkan dengan apakah dengan sumber daya berikut mampu meningkatkan kualitas pelayanan sebagaimana mestinya. Dalam hal ini efektifitas dan efesiensi yang dimaksud adalah bagaimana hubungan antara kegiatan pengobatan yang dilakukan petugas posyandu terhadap pasien gangguan jiwa.

Efektifitas pelayanan posyandu jiwa yang terfokus dengan tingkat kesembuhan pasien dalam pelaksanaan program Posyandu Jiwa terdapat beberapa syarat yang wajib dipenuhi untuk menyatakan apakah program posyandu jiwa di Desa Mojotamping efektif atau tidak adalah sebagai berikut:

a. Perawatan yang didapat penderita gangguan jiwa.

Membicarakan terkait dengan treatment (perawatan) yang didapat oleh penderita gangguan jiwa pihak posyandu memerlukan adanya keikutsertaan peran keluarga ditiap tahapannya.

"Kita harus minta bantuan keluarga mbak, orang gila diajak bicara juga gak bakal paham. Jadi kita mewajibkan untuk pemeriksaan ODGJ harus didampingi keluarga biar nantinya kita bisa mantau kondisi kesehatan pasien" - Keterangan Bu

Rita selaku Pembina Posyandu Jiwa di Desa

Mojotamping pada 22 Oktober 2020.

Berdasarkan keterangan pada hasil wawancara yang dikemukakan oleh Ibu Rita bahwasanya peran keluarga sangat diperlukan terlebih pada awal proses pendiagnosaan yang dilakukan oleh dokter, dokter memerlukan peran keluarga sebagai mediator untuk menentukan golongan gangguan jiwa pada pasien apakah termasuk dalam golongan ringan, sedang, atau berat. Setelah adanya penggolongan tersebut, dokter akan memeriksa pasien, apakah pasien memiliki keluhan lain seperti asam urat, hipertensi, darah rendah, diabetes atau penyakit bawaan lainnya. 
Karena obat - obatan yang dikonsumsi oleh penderita gangguan jiwa tergolong dengan psikotropika, obat - obatan tersebut tidak bisa dikonsumsi dan diambil (dibeli) sembarangan. Obat obatan tersebut memerlukan resep dokter sebagai landasan bahwasanya obat yang akan dikonsumsi oleh penderita gangguan jiwa di Desa Mojotamping aman dan tidak memberikan efek samping yang membahayakan.

Pada tahun 2019, Ibu Rita selaku Pembina Posyandu Jiwa mengemukakan bahwasanya terdapat satu orang yang telah dinyatakan sembuh, kemudian kambuh kembali dikarenakan tidak adanya penyuluhan lanjutan pada keluarga penderita gangguan jiwa apabila sudah dinyatakan sembuh. Menurut pandangan peneliti, hal ini terkesan bahwa pelayanan posyandu jiwa tersebut terkesan sia - sia apabila tidak segera diadakannya penyuluhan lanjutan, hal tersebut juga diperkuat dari hasil wawancara yang peneliti lakukan bersama dengan pihak keluarga yang memiliki anggota keluarga penderita gangguan jiwa yang sudah dinyatakan sembuh kemudian kambuh kembali.

"Kalau untuk sosialisasi itu cuman sekali saja mbak, dilakukan diawal sebelum penerapan program Posyandu Jiwa. Itupun selama tahun 2019 juga baru bapak yang sembuh, itupun bulan - bulan akhir. Masuk tahun 2020, gak ada posyandu dan obat juga berhenti soalnya kan udah sembuh, eh bulan ini kok tiba - tiba saya tau bapak ngomong - ngomong sendiri ya langsung telfon pembinanya mbak". Keterangan salah satu warga dari pihak keluarga yang memiliki anggota keluarga ODGJ pada 22 Oktober 2020.

b. Cara mengatasi permasalahan apabila penderita gangguan jiwa kambuh

Dalam proses pelayanan kesehatan bagi penderita gangguan jiwa, ada dimana banyak sekali kasus ODGJ mengamuk, atau merusak barang, tidak mengenakan pakaian, atau bahkan berbicara sendiri merupakan hal yang sering dijumpai. Di Desa Mojotamping sendiri yang menerapkan Posyandu Jiwa tidak terlepas dari permasalahan tersebut. Ibu Rita selaku pembina posyandu terkadang mendapatkan keluhan terkait dengan beberapa penderita gangguan jiwa yang kambuh.

"Kalau ngomongi kambuh itu udah sering mbak, bahkan warga sendiri juga sudah hafal, dan alhamdulillah disini ODGJnya gak ada yang sampe jalan keluar rumah. Cuman saya kadang juga capek, soalnya ada penderita ODGJ kalau kambuh itu bener gak marah marah tapi kadang berhentikan paksa tiap orang jualan yang lewat di depan rumahnya. Iya kalau orang tuanya mampu buat belikan, kalau gak mampu itu lo saya kasihan sama orang tuanya jadi kadang saya yang bayar penjualnya sama ngasih pengertian ke penjualnya biar gak ada salah paham." Keterangan dari Ibu Rita selaku Pembina Posyandu Jiwa Desa Mojotamping pada 22 Oktober 2020.

Berdasarkan keterangan tersebut, cara mengatasi penderita gangguan jiwa yang kambuh pembina posyandu hanya mendatangi pihak keluarga yang melaporkan tentang anggota keluarga yang menderita gangguan jiwa, kemudian pembina akan datang untuk menenangkan ODGJ tersebut, untuk menenangkannya pihak pembina hanya berbicara dengan nada yang tenang dan bersahabat untuk penderita gangguan jiwa agar ODGJ tidak panik dan takut serta untuk menghindari beberapa kejadian yang tidak diinginkan.

Kemudian keterkaitan dengan efisiensi sebagai bentuk ketanggapan proses pelayanan diperlukan sebagai bentuk untuk mempercepat proses pelayanan dalam menghadapi permasalahan seperti lupa untuk menjemput pasien, dan pasien yang tidak dapat hadir untuk melakukan pemeriksaan rutin, pihak petugas posyandu akan mengirimkan obat - obatan yang dibutuhkan berdasarkan rekam medis pasien. Dengan menggunakan cara tersebut, diharapkannya tingkat keberhasilan penyembuhan dapat mencapai sasaran dengan efektif dan efisien. Tetapi permasalahan yang peneliti temukan dalam proses wawancara, dalam pelaksanaan Posyandu Jiwa ini pada tahun 2019 yang bertepatan pada bulan April - Juli, tidak melaksanakan kegiatan dikarenakan Bu Rita sebagai pembina posyandu ditugaskan ke luar kota, dan tidak ada pengganti untuk melaksanakan posyandu jiwa. Sementara pada tahun 2020, pelaksanaan posyandu jiwa sempat berjalan pada bulan Januari - Februari dan kemudian berhenti pada bulan Maret hingga saat ini dikarenakan pandemi Covid - 19.

"Sebenernya banyak mbak yang pengen Posyandu Jiwa ini tetep lanjut, cuman kita gak berani melaksanakan karna belum ada surat perintah dari pemerintah setempat 
untuk mengadakan lagi, jadi kita hanya bisa memberikan obat dan memeriksa ke rumah pasien masing - masing, itupun dari pihak kader hanya 2 orang saja yang kerumah jadi kita benar - benar membatasi mbak" Keterangan Ibu Rita selaku Pembina Posyandu Jiwa di Desa Mojotamping pada 22 Oktober 2020.

Sedangkan untuk pelaksanaan posyandu balita dan posyandu lansia, pihak posyandu Desa Mojotamping juga mengarahkan untuk langsung menuju Puskesmas Bangsal sebagai sarana pengganti peran posyandu yang ada di desa.

3. Kesopanan dan keramahan pelaku bisnis/pelayanan.

Berdasarkan KBBI, arti kata sopan merupakan bentuk kata yang menggambarkan mengenai attitude (tingkah laku) yang baik, sedangkan bentuk kata ramah merupakan bentuk kata yang menggambarkan mengenai cara berkomunikasi atau cara penyampaian yang baik. Dalam point ini, peneliti menekankan kepada kegiatan sosialisasi tentang program Posyandu Jiwa. Unsur kesopanan dan keramahan yang terlibat, dikarenakan pemikiran masyarakat yang masih tradisional yaitu menghubungkan antara gangguan jiwa dengan keagamaan (rasa kurang bersyukur). Oleh karenanya, dalam pelaksanaan sosialisasi ini diharapkan agar memberikan timbal balik yang sesuai harapan.

Bermula dengan adanya kebijakan pemerintah provinsi melalui Surat Keputusan Gubernur Jawa

Timur Nomor 460/11166/031/2014 tentang Pembebasan Skizofrenia yang Dipasung, membuat pemerintah kabupaten/kota melaksanakan inovasi program untuk menekan angka pemasungan di Jawa Timur. Pemerintah Kabupaten Mojokerto melalui Dinas Kesehatan membuat inovasi program Posyandu Jiwa yang akan dilaksanakan oleh posyandu. Keterlibatan puskesmas dalam program Posyandu Jiwa sebagai penyedia tenaga medis dan obat - obatan. Karena program tersebut tergolong baru, sosialisasi dilakukan oleh pihak puskesmas sebagai jembatan awal dimulainya Program Posyandu Jiwa. Puskesmas Bangsal sebagai perwakilan dari pihak Kecamatan Bangsal dan Dinas Kesehatan Kabupaten Mojokerto, melaksanakan sosialisasi dengan mengundang pamong (tokoh) desa, dan warga di Kecamatan Bangsal yang memiliki anggota keluarga penderita gangguan jiwa.
"Kalau terkait sosialisasi kita mengumpulkan pamong desa dan warga sekitar yang punya keluarga penderita ODGJ mbak, kita sosialisasinya dilaksanakan dengan membagi jadwal 1 hari di desa ini, 1 hari di desa sana untuk mempermudah pekerjaan karna petugas yang terbatas mbak". - Keterangan salah satu Pegawai Puskesmas Bangsal pada 17 November 2020.

Pelaksanaan sosialisasi tersebut, menyajikan materi terkait dengan apa itu gangguan jiwa, apa yang harus dilakukan apabila memiliki keluarga penderita gangguan jiwa, dan bagaimana cara merawat anggota keluarga yang penderita gangguan jiwa tanpa dipasung. Materi yang disampaikan tersebut, dengan menerapkan prinsip keramahan yang memperhatikan dan memilah kata - kata yang tidak menyinggung dan bisa diterima oleh warga setempat.

"Ya awalnya juga gak terima, cuman masalah segitu aja kok bisa sampai gila. Tapi ya alhamdulillah adanya program ini, keluarga jadi gak mikir ke arah sana mbak, jadi kita ya ngerawatnya ikhlas" - Keterangan salah satu warga desa yang memiliki keluarga pengidap ODGJ pada 22 Oktober 2020.

Tidak hanya berhenti disitu saja, petugas posyandu dengan sigap membentuk kader Posyandu Jiwa yang diperoleh melalui ibu - ibu PKK yang diwakili dari tiap dusun di Desa Mojotamping. Perwakilan tersebut yang berisikan warga setempat, difungsikan sebagai sarana untuk menyisir keberadaan ODGJ di Desa Mojotamping dengan dibantu oleh warga desa, pihak puskesmas, dan aparat keamanan. Penyisiran yang dilakukan tersebut, menghasilkan metode sosialisasi dengan mendatangi tiap rumah warga yang memiliki keluarga ODGJ untuk melihat kondisi ODGJ selama ini.

Dengan melakukan penyisiran di Desa Mojotamping ditemukan fakta bahwasanya rata - rata penderita gangguan jiwa disebabkan dengan permasalahan ekonomi, rumah tangga, dan paling banyak adalah perihal asmara. Hal tersebut diperkuat dengan hasil wawancara yang dilakukan peneliti pada Pembina Posyandu.

"Kalau rata - rata di Mojotamping itu penyebabnya ya kayak gangguan jiwa pada umumnya mbak. Masalah ekonomi ya biasa namanya juga ekonomikan pasti pasang surut, kalau masalah rumah tangga sama 
asmara itu kayak jadi satu gitu lo mbak. Bahkan walau gangguan jiwa, juga ada ODGJ yang saling suka, kadang cemburu kalau difoto atau makan gitu gak sebelahan. Pokoknya aneh - aneh lah mbak". Keterangan Ibu Rita selaku Pembina Posyandu Jiwa di Desa Mojotamping pada 22 Oktober 2020.

Penyisiran yang dilakukan secara berhati - hati dengan meminta ijin dari pihak keluarga, menunjukkan bahwasanya bentuk kesopanan inilah yang dapat dilihat dari feedback warga desa terhadap program tersebut, dengan membuka diri untuk permasalahan keluarga ODGJ dan menjadikan petugas posyandu jiwa sebagai sandaran apabila pasien tersebut kambuh.

Bentuk kesopanan dan keramahan inilah yang disajikan dalam program Posyandu Jiwa untuk

mempertahankan dan meningkatkan kualitas pelayanan. Akan tetapi, dengan bentuk kesopanan dan keramahan inilah tetap saja terdapat warga yang merasa malu dan pada akhirnya menutup diri kepada warga sekitar karena memiliki keluarga pengidap gangguan jiwa dengan umur yang masih sangat muda. Karena permasalahan tersebut, pihak posyandu dan puskesmas setempat juga tidak dapat memaksa dan lebih memilih mengurus beberapa warga yang berkeinginan keluarga yang mengidap gangguan jiwa bisa sembuh dan beraktivitas dengan normal kembali.

4. Tanggung jawab dalam penanganan keluhan pelanggan.

Setiap pelayanan tidak akan pernah terlepas dengan adanya keluhan dari pelanggan. Bentuk keluhan tersebut merupakan hubungan timbal balik yang didapat dari penerima pelayanan kepada pemberi

pelayanan sebagai bentuk untuk meningkatkan kualitas pelayanan. Tanggung jawab merupakan bentuk yang sangat krusial, apalagi ketika membicarakan pelayanan pada bidang kesehatan. Karena dalam bidang kesehatan, penanganan keluhan pada pasien menjadi tolak ukur dalam keberhasilan menyembuhkan pasien dan menghubungkan dengan kualitas pelayanan. Dapat dikatakan bahwa semakin banyak pasien yang sembuh maka kualitas pelayanan kesehatan semakin meningkat dalam menangani keluhan pasien.

Posyandu Jiwa yang disajikan di Desa Mojotamping pada tahun 2019 dan tahun 2020 memiliki perbedaan. Pada tahun 2019, pelaksanaan kegiatan Posyandu Jiwa dapat dilaksanakan setiap 1 bulan sekali dengan melakukan pengecekan fisik seperti berat badan (BB), tinggi badan (TB), lipo protein (LP), asam urat (AU), kalium (K), gula darah (GDA) dan obat yang diberikan (TX). Sementara itu pada tahun 2020 karena adanya pandemi Covid - 19, pelaksanaan kegiatan Posyandu Jiwa tidak dapat dilaksanakan karena terdapat larangan dari pemerintah

pusat untuk mengadakan kegiatan yang menggerombol. Hingga pada akhirnya kegiatan Posyandu Jiwa pada tahun 2020 hanya dilaksanakan pada bulan Januari dan Februari saja.

Larangan kegiatan berkumpul inilah, menyebabkan beberapa warga Desa Mojotamping yang memiliki keluarga penderita gangguan jiwa merasa resah. Dikarenakan tanpa adanya Posyandu Jiwa, pengecekan kesehatan secara fisik tidak dapat dilaksanakan, serta pihak posyandu menyarankan untuk langsung membawanya ke Puskesmas Bangsal. Akan tetapi, tetap saja terdapat beberapa pihak keluarga yang merasa kurang setuju karena lokasi antara Desa Mojotamping dan Puskesmas Bangsal terbilang cukup jauh, terlebih apabila membawa pasien ODGJ sangat rawan.

"Sebenernya gak masalah sih mbak kalau bawa ke puskesmas, yang jadi masalah itu kita takut juga sama covid ditambah kalau bawa penderita gangguan jiwa kayak takut aja dan jalan yang dilewati itu jalan besar banyak kendaraan muatan yang lewat. Jadi mending di desa aja." - Keterangan salah satu keluarga pasien penderita gangguan jiwa pada 22 Oktober 2020.

Akhirnya pembina posyandu, tetap menjalankan kegiatan Posyandu Jiwa dengan memberikan alternatif dengan pemberian obat - obatan yang diperlukan pasien penderita gangguan jiwa. Berikut adalah keterangan salah satu keluarga yang memiliki anggota keluarga penderita gangguan jiwa terhadap layanan alternatif yang diberikan pihak posyandu selama masa pandemi.

"Alhamdulillah mbak, petugas posyandu disini baik - baik, saya sambati terkait Pak Anam yang kumat gara - gara ngomong sendiri besoknya obat langsung dianter ke rumah karena saya berhalangan buat ambil ke puskesmas" - Keterangan salah satu keluarga pasien pengidap gangguan jiwa pada 22 Oktober 2020. 
Melalui keterangan berikut, warga setempat mengakui tanggung jawab petugas posyandu dalam penanganan keluhan keluarga terhadap pasien. Karena kondisi pandemi yang meminimalisir kegiatan berkumpul, petugas posyandu memberikan fasilitas berupa pemberian obat kepada pihak keluarga yang memiliki anggota keluarga penderita gangguan jiwa. Prosedur pemberian obat yang harus dijalankan adalah dengan menghubungi pihak kader atau pada pembina posyandu, yang selanjutnya akan diteruskan kepada pihak puskesmas untuk pengambilan obat. Dalam pengambilan obat ini, pihak posyandu memberikan dua pilihan. Pilihan pertama, apabila dirasa segera dibutuhkan pihak keluarga bisa langsung mengambil melalui Puskesmas Bangsal dengan menyebutkan nama pasien dan desa, karena petugas Puskesmas Bangsal sendiri diberikan rekam medis oleh pembina posyandu untuk melaporkan kondisi kesehatan penderita gangguan jiwa. Sedangkan pada pilihan kedua, obat obatan yang dibutuhkan oleh keluarga pasien akan diantar dengan masa tunggu dari menghubungi pihak kader atau pembina posyandu dan pemberian obat kepada keluarga pasien terjeda sekitar 1 hingga 2 hari. Hal ini dikarenakan, kesibukan dari pembina posyandu apabila ditugaskan oleh pihak puskesmas. Apabila dirasa darurat, biasanya hanya dalam waktu kurang lebih 10 menit pembina posyandu sudah sampai di rumah pasien, hal ini dikarenakan jarak antara rumah pembina posyandu dan keluarga pasien yang cukup berdekatan.

Kemudian terkait dengan perawatan yang diberikan selama ini, peneliti melihat bahwa perawatan yang diberikan hanya mengandalkan obat - obatan yang dibutuhkan oleh pasien gangguan jiwa. Obat - obatan yang diberikan tersebut dikonsumsi sesuai dengan anjuran dokter yang telah disediakan oleh Puskesmas Bangsal.

"Kalau untuk perawatannya ya cuman obat obatan aja sih mbak kalau dari pihak puskesmas sama posyandu, selebihnya nanti pihak keluarga kita beri tahu kalau sekiranya penderita gangguan jiwa harus sering sering diajak bicara biar ngerti." Keterangan Ibu Rita selaku Pembina Posyandu Jiwa di Desa Mojotamping pada 22 Oktober 2020.

Pelaksanaan posyandu jiwa dalam bentuk tanggung jawab yang diberikan kepada kader posyandu juga tidak dapat dilewatkan, pembina posyandu yang melaporkan kondisi desa ke puskesmas setempat, sementara para kader posyandu memantau kondisi pasien melalui keluarga serta warga sekitar yang bertempat tinggal berdekatan dengan pasien ODGJ di dusun masing - masing. Pemantauan tersebut dilakukan dengan harapan warga Desa Mojotamping yang mengidap ODGJ tidak berkeliaran atau mengganggu aktivitas warga, melainkan dapat

dikendalikan untuk mempermudah proses penyembuhan.

5. Sedikit banyaknya petugas yang melayani dan fasilitas pendukung lainnya.

Proses pelayanan membutuhkan adanya petugas yang siap melayani permintaan dan keluhan penerima pelayanan atau pelanggan. Hal ini juga dipengaruhi dengan banyak sedikitnya petugas yang dapat dilihat melalui kualifikasi petugas yang ada dalam proses pelayanan tersebut. Selanjutnya fasilitas pendukung juga tidak kalah pentingnya dalam menunjang aspek peningkatan kualitas pelayanan.

Membicarakan tentang sedikit banyaknya petugas yang bertugas di Posyandu Jiwa di Desa Mojotamping terdapat beberapa petugas yang terbagi atas tugasnya masing - masing, antara lain :

1) Kader Posyandu, merupakan salah satu petugas posyandu yang bertugas sebagai pemantau kondisi kesehatan pasien yang berada di tiap dusun yang kemudian akan dilaporkan ke pembina posyandu. Desa Mojotamping yang terbagi atas lima dusun diantaranya adalah Dusun

Mojoroto, Dusun Tamping, Dusun Sumberpandan, Dusun Melaten, dan Dusun Dateng. Kader posyandu ini direkrut melalui ibu - ibu PKK Desa Mojotamping.

2) Pembina Posyandu, merupakan petugas posyandu yang bekerja di Puskesmas Bangsal dan kemudian ditugaskan sebagai pembina posyandu di Desa Mojotamping. Pembina bertugas sebagai pemegang ketersediaan informasi terkait dengan pasien gangguan jiwa yang ada di Desa Mojotamping.

3) Tenaga medis merupakan tenaga kerja yang disiapkan oleh pihak Puskesmas Bangsal untuk melaksanakan pemeriksaan rutin kepada pasien yang bertempat tinggal di Desa Mojoamping. Petugas medis ini terbagi atas dokter dan perawat yang bekerja di Puskesmas Bangsal. Akan tetapi, terdapat kekurangan yang ada dalam kualifikasi 
pada point ini yaitu ketidak tersediaan tenaga medis spesialis kejiwaan.

"Mohon maaf mbak untuk dokter spesialis kejiwaan kita belum menyediakan" Keterangan Ibu Sicus selaku Petugas Puskesmas Bangsal pada 15 November 2020.

Ketidak tersediaan dokter spesialis kejiwaan, dikarenakan ketidakmerataan dokter spesialis kejiwaan. Hal tersebut menyebabkan pelayanan Posyandu Jiwa di Desa Mojotamping hanya terfokus kepada kesehatan fisik, padahal bagi penderita gangguan jiwa kesehatan psikis juga merupakan faktor utama yang sangat penting. Ketidaktersediaan dokter spesialis kejiwaan tersebut disebabkan karena dokter spesialis kejiwaan hanya ada pada wilayah wilayah yang memiliki universitas dengan program studi yang berkecimpung pada dunia kesehatan salah satunya Kota Surabaya.

Jumlah petugas posyandu yang melayani dapat dikatakan sedikit karena hanya berjumlah 6 orang dengan 5 orang kader posyandu dan 1 orang pembina posyandu. Berdasarkan keterangan Ibu Rita selaku pembina posyandu melalui wawancara yang dilaksanakan pada 22 Oktober 2020, petugas puskesmas banyak yang tidak berkeinginan untuk berurusan dengan pasien ODGJ, serta warga desa setempat yang sudah mengenal baik dengan beliau cukup enggan apabila pembina posyandu digantikan dengan orang lain. Permasalahan tersebut juga ditambah dengan pasien ODGJ yang tidak mau berangkat untuk berobat apabila bukan beliau yang menjemputnya.

"Ya sebenernya kalau dibilang sedikit ya sedikit banget mbak, cuman 6 orang ditambah saya. Terus untuk pembina posyandu juga dari pihak puskesmas sudah menawarkan kepada petugas lain tapi banyak yang gak mau kalau urusannya sama ODGJ. Pokoknya kalau saya gak jalan semuanya gak jalan mbak, susahnya disitu." - keterangan Ibu Rita selaku Pembina Posyandu Jiwa Desa Mojotamping pada 22 Oktober 2020.

Selanjutnya terkait dengan fasilitas pendukung lainnya, pada program Posyandu Jiwa di Desa Mojotamping tidak memiliki fasilitas pendukung khusus, melainkan fasilitas pendukung yang diberikan rata - rata hampir sama dengan yang dilaksanakan pada fasilitas kesehatan pada umumnya. Hanya saja yang membuat berbeda adalah adanya pengadaan fasilitas laboratorium yang diadakan secara gratis bagi pasien gangguan kejiwaan. Fasilitas laboratorium tersebut didanai menggunakan dana desa sebagai bentuk dukungan pemerintah Desa Mojotamping terhadap program tersebut, serta rata rata pengidap gangguan jiwa di Desa Mojotamping memiliki penyakit tambahan seperti darah rendah, darah tinggi, diabetes, asam urat dll.

Kuantitas petugas posyandu yang melayani dapat dikatakan cukup sedikit, karena dalam hal ini untuk keberlangsungan posyandu jiwa, pembina posyandu sangat berperan penting. Bahkan berdasarkan keterangan beliau sendiri, banyak petugas yang tidak mau berurusan dengan ODGJ, serta warga desa yang sudah terlanjur nyaman dengan beliau. Hal tersebut ditambah dengan pihak pasien yang tidak mau dijemput dengan orang lain dan harus beliau yang menjemput untuk pelaksanaan pengobatan. Serta terkait dengan fasilitas pendukung pihak desa memberikan fasilitas laboratorium gratis kepada pasien ODGJ melalui dana desa.

6. Berkaitan dengan lokasi, ruangan tempat pelayanan, tempat parkir, ketersediaan informasi, dan petunjuk atau panduan lainnya.

Pelayanan tidak akan pernah terlepas dari beberapa aspek pendukung untuk meningkatkan kualitas pelayanan. Aspek - aspek tersebut antara adalah berkaitan dengan lokasi pelayanan, yang mana lokasi pelayanan tersebut berpengaruh terhadap kemudahan dari penerima pelayanan dalam menjangkau lokasi tersebut. Selanjutnya adalah ruangan tempat pelayanan, ruangan tersebut merupakan aspek yang sangat penting yang mana diperlukan sebagai tempat proses pelayanan. Selanjutnya adalah tempat parkir, tempat parkir sendiri digunakan lahan untuk memarkirkan kendaraan bermotor milik petugas posyandu dan milik keluarga pasien saat mengantarkan pasien melakukan pemeriksaan. Selanjutnya adalah ketersediaan informasi, ketersediaan informasi ini merupakan bentuk pengadaan informasi yang mencakup data pasien dan data obat yang diberikan kepada pasien. Selanjutnya adalah petunjuk dan panduan lainnya, berisikan langkah langkah atau tahapan yang harus disiapkan dan dilakukan oleh keluarga pasien untuk mempercepat proses pendiagnosaan. 


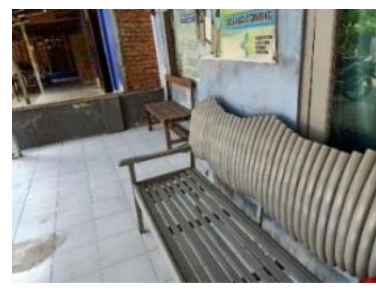

Gambar 1. Lokasi Ponkesdes (Pondok Kesehatan Desa) untuk Pelaksanaan Posyandu Jiwa

Sumber : Dokumentasi Peneliti Tahun 2020

Lokasi dalam pelaksanaan Posyandu jiwa di Desa Mojotamping dilaksanakan di Ponkesdes (Pondok Kesehatan Desa). Tempat tersebut dapat dikatakan sangat strategis karena berdekatan dengan Sekolah Dasar Negeri Mojotamping. Ponkesdes tersebut tidak hanya digunakan sebagai Posyandu Jiwa saja, tetapi juga melayani Posyandu Balita dan Posyandu Lansia yang sudah dijadwalkan secara bergiliran.

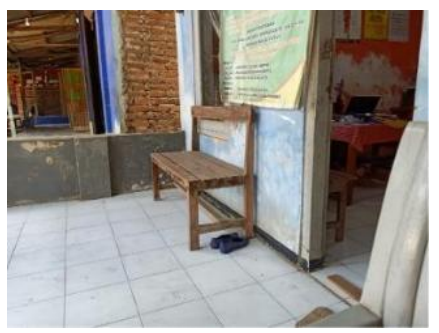

Gambar 2. Ruangan Tempat Pelayanan Posyandu Sumber : Dokumentasi Peneliti Tahun 2020

Ruangan tempat pelayanan yang dijadikan sebagai tempat pendiagnosaan, seperti pada Gambar 2 memiliki ruangan yang cukup sempit. Ruangan tersebut hanya bisa dimasuki oleh 2 sampai dengan 3 orang saja. Kemudian kondisi cat tembok ponkesdes yang mulai mengelupas menyebabkan rasa ketidaknyamanan dan ketidak bersihan yang muncul dalam benak peneliti saat tiba dilokasi tersebut.

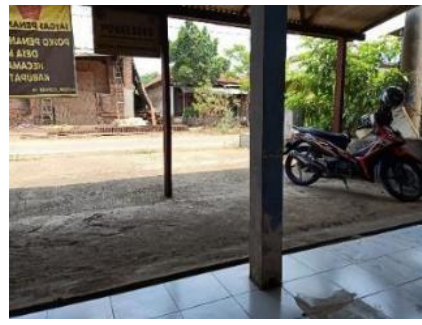

Gambar 3. Tempat Parkir

Sumber : Dokumentasi Peneliti Tahun 2020

Lahan parkir yang digunakan sebagai tempat memarkir kendaraan petugas dan keluarga pasien dalam lahan ponkesdes, hanya bisa memuat sebanyak 5 sampai dengan 6 kendaraan bermotor. Akan tetapi dalam pelaksanaannya apabila kondisi pemeriksaan ramai maka lahan parkir tersebut difungsikan sebagai ruang tunggu pasien dengan keluarganya agar tidak menganggu proses pendiagnosaan.

Keberadaan informasi dalam dimensi kualitas pelayanan memuat informasi terkait dengan program pelayanan tersebut dijalankan. Dalam konteks ini memuat, antara lain :

1) Jadwal penanganan pasien

Posyandu jiwa memiliki jadwal penanganan pasien yang dilakukan rutin setiap satu bulan sekali. Biasanya dilaksanakan pada hari Sabtu atau Minggu dengan jam operasional dimulai jam 08.00 pagi hingga paling lambat jam 15.00 sore. Pada tahun 2019 pelaksanaan Posyandu Jiwa ini dimulai, terdapat 22 pasien yang terdaftar di Desa Mojotamping. Pelaksanaan posyandu jiwa pada tahun 2019 dilaksanakan pada bulan Januari, Februari, Maret, Agustus, Oktober, November dan Desember. Diluar dari bulan - bulan tersebut, Posyandu Jiwa tidak dilaksanakan karena pembina posyandu yang berhalangan. Kemudian pada tahun 2020 pelaksanaan Posyandu Jiwa dilaksanakan pada bulan Januari dan Februari, sementara pada bulan Maret hingga Desember tidak dapat dilaksanakan. Karena lokasi yang digunakan Posyandu Jiwa sama dengan lokasi Posyandu Lansia dan Balita, pelaksanaannya dibagi berdasarkan jadwal yang telah dibuat oleh pembina posyandu.

2) Terapi yang diberikan

Pelaksanaan Posyandu Jiwa dalam pengobatan penderita gangguan jiwa dibutuhkan terapi yang tepat untuk mempercepat proses penyembuhan. Walaupun proses penyembuhan penderita gangguan jiwa berbeda - beda, tetapi tetap saja terapi diperlukan sebagai pengobatan secara psikis dan tidak terfokus pada fisik. Akan tetapi setelah peneliti melakukan penelitian Posyandu Jiwa di Desa Mojotamping, pihak posyandu hanya memberikan obat - obatan dan memantau kondisi pasien melalui rekam medis yang dicatat setiap bulannya. Karena kebanyakan dari penderita gangguan jiwa di Desa Mojotamping juga memiliki penyakit bawaan seperti hipertensi, asam urat dll.

3) Prosedur terkait dengan penanganan ODGJ yang kambuh atau lepas.

Kambuh merupakan hal yang sudah sering terjadi bagi pembina dan kader Posyandu Jiwa. Apabila salah satu warga menemukan adanya penderita gangguan jiwa yang kambuh bagi warga sekitar yang mengetahui nomor ponsel pembina posyandu bisa langsung menghubungi beliau, sedangkan apabila 
warga tidak mengetahui nomor ponsel pihak posyandu, warga bisa melaporkan ke RT atau RW kemudian akan diteruskan ke kader posyandu yang sudah ditempatkan ditiap - tiap dusun. Kemudian kader posyandu akan menghubungi pembina dan aparat keamanan (apabila diperlukan) untuk mengamankan ODGJ tersebut.

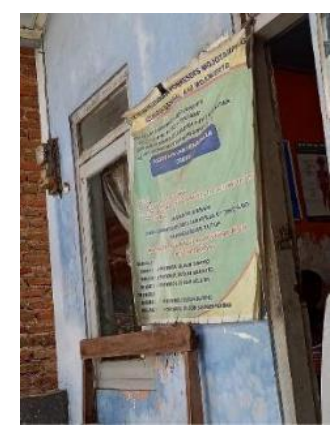

Gambar 4. Ketersediaan Petunjuk

Sumber : Dokumentasi Peneliti Tahun 2020

Ketersediaan petunjuk atau panduan yang telah ditempelkan di jendela depan ponkesdes, membuktikan adanya panduan yang perlu diperhatikan dalam memeriksakan pasien baik pasien gangguan jiwa atau pun pasien umum. Langkah - langkah tersebut antara lain membawa kartu BPJS atau KIS dan membawa KTP atau fotocopy KK, untuk kemudian didata oleh petugas posyandu untuk mendapatkan fasilitas laboratorium dan pengobatan secara gratis bagi pasien gangguan jiwa. Akan tetapi, ketersediaan petunjuk yang diberikan pada pihak warga desa melalui papan informasi yang ada di Ponkesdes terlihat warnanya yang sudah mulai pudar, dan beberapa selotip yang menempel pada papan informasi tersebut. Walaupun prosedur atau panduan yang diberikan sama dengan program posyandu lainnya, akan tetapi jadwal dan program posyandu jiwa tidak dicantumkan pada papan informasi tersebut, maka dari itu pihak warga desa mengandalkan pemberitahuan yang akan disampaikan pihak kader posyandu dari masing masing dusun.

Pelaksanaan kegiatan posyandu jiwa di Desa Mojotamping yang berkaitan dengan tempat pelayanan, peneliti merasa masih kurang maksimal, terlebih ruangan pelayanan dan lahan parkir yang relatif sempit. Kemudian pihak pembina posyandu yang bertugas untuk mencatat pelaksanaan kegiatan selama program posyandu belum dapat dikatakan maksimal karena terkesan berantakan, serta pelaksanaan program posyandu yang belum terlaksana rutin tiap bulannya pada tahun 2019. Selanjutnya pada ketersediaan petunjuk atau panduan lainnya, untuk posyandu jiwa masih belum dituliskan dalam papan informasi tersebut, serta papan informasi yang digunakan hingga saat ini banyak ditemukan selotip serta warna papan informasi yang sudah terbilang pudar.

7. Berhubungan dengan kondisi lingkungan, kebersihan, ruang tunggu, fasilitas musik, AC, alat komunikasi, dll.

Selain tempat pelayanan, kondisi yang ada dalam ruang lingkup pelayanan tersebut mempengaruhi kualitas pelayanan yang ada. Dalam hal ini, penekanan pada point ini menunjukkan adanya kenyamanan dan kepuasan penerima pelayanan.

Berkaitan dengan kondisi lingkungan di lokasi tersebut, rata - rata mata pencaharian penduduk di Desa Mojotamping adalah sebagai pembuat batu bata merah. Pembuatan batu bata merah tersebut menandakan bahwa kondisi lingkungan di desa tersebut sangat berpasir. Karena berpasir inilah, mudah sekali tertiup angin dan mengakibatkan kondisi kebersihan pada teras ponkesdes menjadi berkurang karena adanya debu. Hal itu juga disampaikan oleh Ibu Rita selaku pembina Posyandu Jiwa bahwa sudah lelah untuk membersihkan apalagi kalau kondisinya lagi berangin dan panas, biasanya beliau menunggu malam untuk membersihkan teras ponkesdes. Tidak hanya itu, kondisi cat tembok yang mengelupas juga menambah beban pekerjaan untuk Ibu Rita untuk membersihkannya.

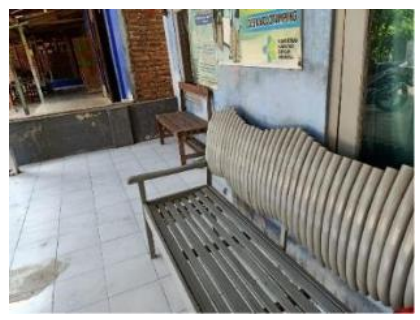

Gambar 5. Ruang Tunggu Ponkesdes

Sumber : Dokumentasi Peneliti Tahun 2020

Ruang tunggu yang digunakan pada saat pelaksanaan posyandu adalah terletak di teras ponkesdes. Ruang tunggu tersebut hanya difasilitasi oleh 2 bangku kayu yang panjang, selebihnya adalah duduk di tembok yang merupakan sekat antara bangunan ponkesdes dengan bangunan yang lainnya.

Karena Ponkesdes digunakan sebagai Posyandu Jiwa, Lansia dan Balita fasilitas yang diberikan juga berbeda. Terlebih pada fasilitas untuk posyandu jiwa menyediakan layanan antar jemput pasien dan fasilitas 
laboratorium gratis yang didanai oleh pemerintah Desa Mojotamping.

\section{PENUTUP}

\section{KESIMPULAN}

Dari hasil dan pembahasan yang ada, dapat disimpulkan melalui teori Vincent Gesperz bahwa Pemerintah Kabupaten Mojokerto melalui Dinas Kesehatan untuk membuat program yang bernama Posyandu Jiwa pada tahun 2019 sebagai bentuk pelayanan publik yang dapat menolong masyarakat yang mengalami gangguan jiwa atau memiliki keluarga yang mengidap gangguan jiwa. Salah satu desa yang hingga saat ini masih menerapkan program tersebut adalah Desa Mojotamping. Dibawah pengawasan Puskesmas Bangsal, pelaksanaan Posyandu Jiwa di Desa Mojotamping dilaksanakan setiap satu bulan sekali pada minggu ke dua atau pada pertengahan bulan yang jatuh pada hari sabtu. Posyandu Jiwa dibuka pada pukul 08.00 WIB pagi dan berakhir paling lambat pada pukul 15.00 WIB sore. Ketika proses pelayanan terjadi, petugas posyandu biasanya akan melakukan penjemputan kepada pasien ODGJ. Penjemputan tersebut dilaksanakan sebagai bentuk rasa percaya pasien ODGJ kepada petugas posyandu untuk diantar berobat. Selanjutnya pasien ODGJ akan mendapatkan pendampingan oleh pihak keluarga sebagai perantara untuk menjelaskan terkait dengan penyebab dan membantu dalam proses pemulihan, walaupun setiap pasien memiliki masa pemulihan yang berbeda beda rasa tanggung jawab dari kader posyandu tetap ada dengan memfasilitasi pemberian obat - obatan dan fasilitas pemeriksaan gratis yang didanai oleh dana desa. Terkait dengan keramahan dan kesopanan kader posyandu ditunjukkan melalui cara petugas posyandu mengajak pasien ODGJ untuk bernyanyi, komunikasi agar tidak bosan untuk menunggu giliran pemeriksaan. Tanggung jawab petugas posyandu juga terlihat melalui pemenuhan kebutuhan obat walaupun masa pandemi berlangsung, serta pihak keluarga berkoordinasi dengan pihak kader posyandu sebagai bentuk pengawasan dan pemantauan kondisi pasien. Selanjutnya petugas yang melayani terbagi atas petugas medis, petugas kesehatan, dan lima orang kader posyandu. Akan tetapi, petugas medis dan petugas kesehatan tidak memiliki dokter spesialis kejiwaan. Kemudian situasi dan kondisi lingkungan yang ada dalam hal kebersihan dirasa cukup bersih diawal tetapi saat proses pemeriksaan berlangsung kondisi kebersihan menurun. Fasilitas ruang tunggu yang diberikan berada di luar ruangan dan diberi kursi plastik. Melalui upaya inilah peneliti menyatakan kualitas pelayanan program Posyandu Jiwa di Desa Mojotamping terbilang cukup bagus, hanya kurang dari segi lokasi dan ruang tunggu dan proses perawatan.

\section{SARAN}

Saran yang dapat peneliti berikan terkait dengan "Kualitas Pelayanan Program Posyandu Jiwa Terhadap Pasien ODGJ (Orang Dengan Gangguan Jiwa) di Desa Mojotamping Kabupaten Mojokerto" adalah sebagai berikut :

1. Saran peneleti kepada pihak posyandu adalah memberikan edukasi terkait dengan penyebab, bahaya, cara penanganan dan penyembuhan pasien ODGJ kepada pihak keluarga yang tidak mendukung program tersebut. Kemudian pihak posyandu juga dapat mengajak warga desa dan perangkat desa untuk membujuk keluarga tersebut agar dapat terlaksananya proses penyembuhan pasien.

2. Pihak puskesmas dapat melaksanakan perekrutan dokter spesialis kejiwaan melalui PNS atau melalui pegawai kontrak untuk mempercepat proses

penyembuhan pasien. Kemudian perlu diadakannya pelatihan bimbingan teknis yang dapat dilaksanakan oleh pihak puskesmas untuk memberikan edukasi terkait dengan penanganan pasien ODGJ agar tidak ketergantungan tinggi dengan pembina posyandu.

3. Agar pengobatan dan perawatan yang diberikan tidak sia - sia, pihak puskesmas dan posyandu bisa melaksanakan penyuluhan lanjutan bagi keluarga yang memiliki anggota keluarga ODGJ untuk mencegah kambuhnya gangguan jiwa kembali.

4. Terkait dengan tempat pelayanan dan lahan parkir, pihak desa dapat mencarikan lokasi yang lebih memadai untuk dilaksanakannya pelayanan kesehatan di ponkesdes, agar memberikan kenyamanan pada pasien. Papan informasi yang memuat petunjuk untuk melaksanakan posyandu jiwa, diperlukan adanya peremajaan kembali dan mencantumkan posyandu jiwa sebagai program kesehatan desa dan jadwal pelaksanaan posyandu jiwa agar pelaksanaan rutin ditiap bulannya. 


\section{DAFTAR PUSTAKA}

Andriani, A.-. (2017). Hubungan Mutu Pelayanan Kesehatan Dengan Kepuasan Pasien Diruangan Poli Umum Puskesmas Bukittinggi. Jurnal Endurance, 2(1), 45.

Apriyani, T. (2019). Indonesia Darurat Depresi Namun Minim Praktisi. Yoursay.Suara.Com. https://yoursay.suara.com/news/2019/12/23/09 3643/indonesia-darurat-depresi-namunminim-praktisi

Budianto, E. E. (2019). 5 Tahun Dipasung, 2 Penderita Gangguan Jiwa di Mojokerto Dibebaskan. DetikNews.Com. https://news.detik.com/berita-jawa-timur/d4458899/5-tahun-dipasung-2-penderitagangguan-jiwa-di-mojokerto-dibebaskan

Chariris, M. (2020). 1221 Warga Alami Gangguan Jiwa Dipicu Stres dan Depresi. Radar Mojokerto. https://radarmojokerto.jawapos.com/read/2020/ 10/14/218958/1221-warga-alami-gangguanjiwa-dipicu-stres-dan-depresi

Crowe, Allison \& Averett, P. (2015). Attitudes of Mental Health Professionals toward Mental Illness : A Deeper Understanding. Journal of Mental Health Conseling, 37(1), 47-62.

Dinas Kesehatan Provinsi jawa timur. (2019). Profil Kesehatan Provinsi Jawa Timur Tahun 2019. Surabaya : Dinkes Prov Jatim.

Eprilianto, D. F., Sari, Y. E. K., \& Saputra, B. (2019). Mewujudkan Integrasi Data Melalui Implementasi Inovasi Pelayanan Kesehatan Berbasis Teknologi Digital. JPSI (Journal of Public Sector Innovations), 4(1), 30.

Handayani, S. (2016). Tingkat Kepuasan Pasien Terhadap Pelayanan Kesehatan Di Puskesmas Baturetno. In Profesi (Profesional Islam) : Media Publikasi Penelitian (Vol. 14, Issue 1, p. 42).

Hartono, J. P. (2007). Analisis Proses Perencanaan Kebutuhan Obat Publik Untuk Pelayanan Kesehatan Dasar (PKD) Di Puskesmas Se Wilayah Kerja Dinas Kesehatan Kota Tasikmalaya. Tesis Magister Ilmu Kesehatan Masyarakat, Konsentrasi Administrasi Kebijakan Kesehatan, Universitas Diiponegoro, Semarang, 1-179.

HIMPSI. (2020). Terms of Reference: Seri Sumbangan Pemikiran Psikologi untuk Bangsa Ke-5. Himpsi.or.Id, September 2019, 13. https://himpsi.or.id/blog/pengumuman2/post/kesehatan-jiwa-dan-resolusipascapandemi-di-indonesia-panduan-penulisan132

Kasl, S. V., \& Cobb, S. (2013). Health Behavior, Illness Behavior, and Sick-Role Behavior.
Archives of Environmental Health, 12(4), 531541.

Kemenpan. (2003). Keputusan Menteri Pendayagunaan Aparatur Negara Nomor 63 Tahun 2003 Tentang Pedoman Umum Penyelenggaraan Pelayanan Publik. Jakarta : Kemenpan.

Machmud, R. (2008). Manajemen Mutu Pelayanan Kesehatan. Jurnal Kesehatan Masyarakat Andalas, 2(2), 186.

Pratiwi, D. P., \& Niswah, F. (2018). Strategi Peningkatan Layanan Kesehatan Melalui Program Jemput Bola Pasien Urung Kunjung (Jebol Pasung) Di Puskesmas Geger Kabupaten Madiun. Digilib.Unesa, 1-8.

Riskesdas, K. (2018). Hasil Utama Riset Kesehatan Dasar (RISKESDAS) 2018. In Kementrian Kesehatan RI (Vol. 44, Issue 8, pp. 1-200).

Saleh, M. R. (2018). The Burden of Mental Illness : An Emerging Global Disaster. Journal of Clinical and Health Science, 3, 5-12.

Suwarno, Y. (2008). Inovasi di Sektor Publik. STIA LAN.

Ulfa, A. T. (2018). Implementasi Program Administrasi Terpadu Manajemen Pasung (Atm-Pasung) Di Kecamatan Buduran Kabupaten Sidoarjo. Jurnal Mahasiswa Unesa.

Warsono, H., Qurniawati, D. R., Sitorus, H., \& Fajar S., S. M. (2018). Inovasi Layanan Mpospay Dan Free Pick Up Pos Indonesia Dalam Peningkatan Kualitas Pelayanan (Studi Pada Kantor Pos Semarang 50000). JPSI (Journal of Public Sector Innovations), 2(2), 44.

WHO. (2017). Depression and Other Common Mental Disorders : Global Health Estimates.

WHO. (2019). Mental Health in the Workplace. https://www.who.int/mental_health/in_the_wor kplace/en/

Wicaksono, M. A. S., \& Susilowati, I. (2019). Perlindungan Hukum Hak Penyandang Gangguan Jiwa yang Menggelandang di Kabupaten Jombang. Digilib.Unesa, 53(9), 1689-1699.

Widoanti, D., \& Meirinawati. (2020). Kualitas Pelayanan Lesung Si Panji ( Lenyapkan Pasung Dan Memanusiakan Pasien Jiwa ) Dinas Kesehatan Kabupaten Lamongan ( Studi Kasus pada Puskesmas Laren ). Publika Unesa, Vol 8, No, 1-13. 
Publika. Volume 9 Nomor 2 Tahun 2021, 53-68 